\title{
Capabilities expansion for marginalised migrant youths in Johannesburg: The case of Albert Street School
}

CrossMark

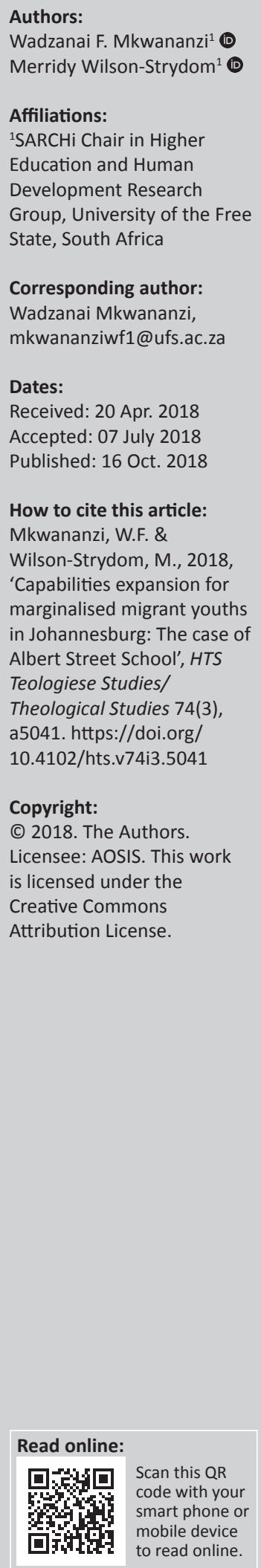

In this article, we used the capability approach as normative grounding to analyse a particular faith-based intervention targeting 'youth at the margins' - in this instance, marginalised migrant youths from Zimbabwe living in Johannesburg, South Africa. We used Albert Street School (AS School), run by Johannesburg's Central Methodist Church, as our case study to show how this faith-based organisation, through its focus on education, created not only spaces for marginalised youths to aspire towards a better life but also practical opportunities to convert their aspirations into action. Drawing on first-hand accounts of 12 Zimbabwean migrant youths who had completed schooling at AS School, as well as of representatives of both the school and the CMC, the article first sketches the Zimbabwe-South Africa migration context post 2000. A discussion then follows of AS School as a faith-based intervention which addresses the constrained capability for education amongst marginalised migrant youths.

\section{Introduction}

There is a growing amount of literature globally considering the interface of religion and development (Alkire 2006; Deneulin \& Bano 2009; Swart \& Nell 2016), including human development (Deneulin \& Zampini-Davies 2016, 2017). One strand of this literature takes particular account of the contribution of faith-based organisations (FBOs) in development processes (Chaves 2001; Occhipinti 2015; Olarinmoye 2012). Clarke and Jennings (2008:6) refer to a 'faith-based organisation' as an organisation whose activities are inspired and guided by 'teachings and principles of the faith or a particular interpretation within the faith'. Although the role of FBOs in community development has been overlooked in discussions on development (Willis 2013), their contribution in helping those in need and working towards improving the human condition cannot be denied. As Alkire (2006:3) notes, FBOs are often 'significant purveyors of education, service delivery and other non-market goods', thus making their contribution noteworthy in both community and human development.

The role of religious schools in human development in particular was highlighted in the 2004 World Development Report which focused on services to the poor (World Bank 2004). Beyond education, the importance of FBOs in the context of migration, both within and amongst countries, has also received significant attention (Fiddian-Qasmiyeh 2011). The United Nation's Fourth Annual Symposium on the Role of Religion in International Affairs, which took place in January 2018, focused specifically on displacement and migration and the role of FBOs in working towards inclusion and justice for the displaced (Act Alliance 2018). This article is located within and seeks to contribute to the debates about the role of FBOs in education provision and in the space of migration, with a particular focus on youth.

When considering the role of FBOs in young people's lives, we draw on Amartya Sen's capability approach which sees development as the process of creating opportunities for all people to be and do what they value (Sen 1999). This approach allows for a distinction to be drawn between how people can function (their functionings or the beings and doings they have actually achieved, which constitute well-being) and the actual opportunities (capabilities) people have to be and do what they value, regardless of whether they use these opportunities. The capability approach brings values essential for human flourishing (such as respect and dignity) to the centre of development thinking, a move that is well aligned with the work of FBOs (Deneulin 2009). The safeguarding of such values becomes essential for advancing human development. Another key aspect of the capability approach is that it recognises the importance of education for development, as well as the capabilities to aspire and imagine and work towards a better future (Conradie \& Robeyns 2013). Individual agency - defined as the ability to take action and bring about change in one's life - is also a central concept of this approach (Sen 1999). 
Particularly useful though is the manner in which the capability approach seeks to take account of both the agency of individuals and structural and/or institutional factors. We draw on the generative idea of social competence as conceptualised by Stewart (2013) and Deneulin and ZampiniDavies (2016). These authors use the capability approach to argue that the functioning of institutions (FBOs in this case) has important effects on the expansion and/or limitation of people's capabilities. Potentially, institutional arrangements enable individual freedom to convert available opportunities and resources (Calitz, Wilson-Strydom \& Walker 2016) into 'expanded participation' in social, economic and/or political matters. The conversion of these opportunities requires action from the recipient of the services. Therefore, we need to consider the role of FBOs together with the agency of young people to use available institutions to form aspirations and create new capabilities - which is what this article seeks to do.

Using the capability approach as our normative grounding, we analyse a particular faith-based intervention targeting 'youth at the margins' - in this instance, marginalised migrant youths from Zimbabwe living in Johannesburg, South Africa. As noted by Robeyns (2017:27), a normative grounding is 'prescriptive' and requires an ethical standard on what ought to be done. We posit that the evaluation of the migrant youths' quality of life and educational aspirations formation ought to be based on their individual freedoms and opportunities. This is in line with Sen's argument - that the freedom to achieve well-being is of primary importance and can be evaluated by looking at the opportunities or capabilities that individuals have in pursuing what they have reason to value (Robeyns 2011, 2017). Therefore, this position embraces a notion of what society and development ought to look like if they are to be all-inclusive.

We used Albert Street School (AS School) run by Johannesburg's Central Methodist Church (CMC) as our case study of how an FBO, through its focus on education, created not only spaces for marginalised youths to aspire towards a better life but also practical opportunities to convert their aspirations into action.

Whilst there is arguably a common understanding of the concept of 'youths' or 'young people', it is a concept that is technically defined in multiple ways. In this article we focus particularly on migrant youths aged between 18 and 35 years, based on the South African National Youth Commission Act (No. 19 of 1996) that describes youths as people from 14 to 35 years of age (Republic of South Africa government 1996). Many of the youths in the study had migrated to South Africa as minors, but they were all 18 years and older at the time of interviews; thus, ethical research requirements were met. Because of the complexity of defining and categorising migrants, we use the term 'marginalised migrants' to denote refugees, asylum seekers and migrants without formal documentation.

\section{Methodology}

We conducted in-depth, face-to-face interviews with 26 migrant youths (15 men and 11 women aged between 21 and
33 years) from Zimbabwe. The interviews explored the migrants' everyday experiences, the capabilities they viewed to be important, their well-being and their aspirations for educational continuation. The research was conducted in central Johannesburg and focused on migrant youths who had resided at, or had accessed services at the CMC refugee shelter before it shut down in December 2014. From the participants, only nine of the young migrant men had migrated whilst under the age of 18 (unaccompanied minors). Upon arrival in South Africa, 12 of the 15 young men had continued with, and ultimately completed, their secondary education at AS School. The young women interviewed had neither successfully completed their secondary education in Zimbabwe nor continued at AS School. This is despite the fact that the opportunity to learn at AS School was available to all migrant children and young people living at the CMC. An explanation provided by some of the research participants for this disparity was that young women can easily find employment in domestic work compared with their male peers. As such, most young women went into the workplace to earn much-needed income rather than completing their schooling. We return to this issue later in the article. Owing to the precarious and sometimes illegal status of the participants, no real names or identifying information will be presented.

\section{Zimbabwe-South Africa migration context post 2000: Exploring reasons for youth migration}

South Africa's democratic transition in the early 1990s and the country's relative wealth compared with its neighbours, together with atrocities such as wars and famine prevailing in Africa, are determinants of increased migration into South Africa (Trimikliniotis, Gordon \& Zondo 2009). To date, many African migrants still endeavour to find economic and political refuge in South Africa, particularly in Johannesburg.

Although migrants to South Africa come from many different countries, a significant number have been fleeing economic and political instability from neighbouring Zimbabwe. A rise in this number has been witnessed since the start of the millennium when Zimbabwe's economic crisis resulted in hyperinflation. In mid-November 2008, hyperinflation peaked at 79.6 billion per cent (Hanke \& Kwok 2009:354), which made it difficult for most citizens to meet their daily needs. For example, in 2008, prices almost doubled each day, making this the second severe case of hyperinflation in modern history (Hanke 2017).

Whilst the crisis affected both young and old, youths were the most affected group (Chirisa \& Muchini 2011). Unemployment, unaffordable commodities and unconducive conditions for entrepreneurship as a result of the unstable currency challenged the basic survival of young people (Mkwananzi \& Wilson-Strydom 2018). In addition, access to basic education became compromised, with education budget cuts leading to increasingly poorer 
educational services (Pswarayi \& Reeler 2012). A UNICEF study highlighted that $94 \%$ of rural schools in Zimbabwe were closed in 2009 - schools that served most of the population (Besada 2011), including some of the youths who were part of our study. Some teachers declined to report for duty, as their salaries had become almost worthless (Dekker 2009). Furthermore, the recruitment of school children to participate in political activities resulted in students' missing out on school activities (Makumbe 2009). Reiterated by the migrant youths in the study, these multiple experiences demonstrate the negative impact of economic and political factors on educational opportunity. As a result of these multidimensional challenges, youths, together with many others, fled across the globe, but particularly to neighbouring countries such as South Africa. However, their hopes of finding a better life in South Africa were met with diverse challenges, such as a lack of jobs, financial challenges and difficulties with documentation. Some of the documentation challenges might be attributed to the legal management of refugees and asylum seekers.

\section{Legal frameworks}

Backed by the South African Constitution, the Refugees Act (No. 130 of 1998) and Immigration Act (No. 13 of 2002) control migration and migrants within South Africa (RSA Government 1998, 2002). The Refugees Act adopts a selfsettling approach for refugees and those seeking asylum, that is, they are required to find means of survival within the country, which include finding work and selfintegrating into local communities. They also have rights to access public services such as healthcare, justice and basic education. The Immigration Act allows visas for migrants who are skilled, tourists or students, in addition to various other categories of permanent and temporary migrants. In what could be seen as a way to strengthen regional relations, South Africa introduced the Zimbabwe Dispensation Project in 2009, allowing Zimbabwean nationals to apply for work, study and business visas under flexible conditions (see Mkwananzi 2017). The move was introduced by the then Minister of Home Affairs, Mr Malusi Gigaba, as a way to regularise illegal migration following increased applications for refugee recognition by individuals fleeing economic and political tensions in Zimbabwe.

In spite of the responsibility to uphold the rights of asylum seekers, refugees and other migrants, the Immigration Act (No. 13 of 2002) allows for the detention, arrest and deportation of illegal migrants, most of whom are often asylum seekers (RSA government 2002). However, within these legal frameworks, there is no comprehensive blueprint on how young marginalised migrants should be treated and transitioned within the self-settling policy, particularly in the case of child migrants. Although there were centres in Johannesburg (UNICEF 2009) that offered services directed at helping these children, it remained unclear how their educational needs would be addressed.

\section{The Central Methodist Church's intervention in the migrant situation}

Whilst non-governmental organisations (NGOs) such as Save the Children and non-profit organisations such as Section 27 and Legal Resources Centre, were also involved in addressing some of the needs of the young migrants, the high number of unaccompanied migrant children at that time was viewed as a humanitarian crisis (UNICEF 2009:1) that required collaborative efforts. The role of the $\mathrm{CMC}$, and later of AS School, can be seen to characterise the role of FBOs in development, namely offering services, shelter and education, as well as changing migrants' attitudes towards their own lives (Carino 2016) through the various programmes offered at the church. All young migrant men and women interviewed acknowledged the role of the church in providing services such as shelter and access to primary and secondary education, in addition to emotional support.

The 2008 xenophobic attacks in South Africa further led to a high number of children of school-going age seeking refuge at the church. Because the CMC had long been providing shelter to disadvantaged individuals from various backgrounds, it was no surprise that during these attacks, it housed approximately 5000 migrants at a time (Kuljian 2013). This is despite the fact that there was not enough space inside the church building, with some migrants, including children, sleeping outside. As a result of the overpopulation at the church, businesses in the vicinity raised concerns about physical security and sanitation, arguing that the state was failing to take the necessary measures to protect refugees and asylum seekers as required by national and international regulatory instruments (Kuljian 2013:185).

The high number of children fleeing to the church - many of whom were unaccompanied minors - became a concern. The major concern was their absence from school, which had them spending their days idling in the streets. The CMC only provided overnight shelter, with residents having to vacate the building during the day for daily church events to take place, resulting in many individuals often having nowhere to go and nothing to do. Consequently, many children were at risk of being recruited for illegal activities by older people for a small fee. Amongst the older migrants, there were many qualified, yet unemployed, professionals, including teachers. Some of the teachers volunteered to teach the children, paving the way for the establishment of AS School.

In the sections that follow, we focus on the social competencies of AS School and what the school was able to be and do. Then we show how what the school was able to be and do was related to the capabilities and expansion of the youths enrolled at the school.

\section{Albert Street School}

AS School started its operations on 07 July 2008, teaching refugee children from Grades 0 to form six. ${ }^{1}$ The school still operates

1.Form six is the highest grade in high school using the Cambridge education system and is equivalent to Grade 12 in South African standards. AS School follows the Cambridge 'form' education system. 
from central Johannesburg in a building that was used as the Methodist Church for Africans before 1994. In previous years, the church had operated as a school for domestic workers and children of domestic workers (Kuljian 2013). When the school opened, it was faced with a number of difficulties, including registration with educational bodies, constrained financial and human resources and a lack of schooling material. To maximise the limited available resources, classes were presented as multigrade. ${ }^{2}$ Language also posed a challenge to the teaching and learning process. For example, some learners could only speak French, whereas most volunteer teachers were English speaking. Furthermore, it was a challenge to get volunteers conversant in any of the local South African languages, a requirement for a full matriculation certificate. ${ }^{3}$

The medium of instruction at the school was English, and the school registered with the British Council, which meant that learners were to sit for Cambridge examinations. Because of documentation challenges, children could not enrol in mainstream schools and, as most of them were unaccompanied minors, they had no source of livelihood. Thus, there was a need for basic supplies, such as food and shelter, which is crucial for successful learning, and at this time, CMC assumed that role (Mkwananzi 2017). Furthermore, the traumatic experiences and dire personal circumstances of the migrant children meant that teachers had to take on multiple roles, that of teacher and parent, so that the children could work to their full potential. With this educational programme running for the children and youths, other migrants resident at the church were free to participate in other skills training activities run by volunteers at the church. These activities included baking, computer lessons, karate and dressmaking. There was also a preschool for toddlers in the church.

Since its inception, AS School has steadily experienced a higher enrolment of boys than girls. Several participants ascribed this disproportion to the fact that, upon arrival in South Africa, many of the female migrants often wed or took up employment in domestic work, most of these live-in jobs, which restricted what they could do in their spare time, such as enrolling in extra educational courses. ${ }^{4}$

In due course, the school adopted French as a language of instruction, as there were children from French-speaking nations such as the Democratic Republic of Congo. (These children also had the opportunity to take extra English classes.) Whilst the school's inception was triggered by a large child migrant community, local citizens could also enrol their children. However, as noted earlier, integrating most of the local languages would have been a challenge, as the school had to operate with limited financial and human resources. Thus, unlike major international NGOs with potentially a larger resource base, the school was, and still is, limited in pioneering larger and wider scale service provision.

\section{For instance, forms threes and fours attending one class. \\ 3.The formal South African school leaving certificate. The full matriculation certificate requires successful completion of one of the local languages, which neither students} nor teachers were fluent in.

4.Further research is needed to better understand this gender dynamic
Accordingly, whilst the school may have grown over the past 10 years, both in enrolments and in infrastructure (e.g., it now has a library), the challenge of funding other infrastructures such as science laboratories and a technology centre still remain. A significant number of unaccompanied minors rely on assistance to register for the Cambridge examinations. The school has succeeded in staying operative because of support from individuals and organisations such as the World Mission Possible and Solidarity Peace Trust, amongst others (Mkwananzi 2017).

The ability of the school to remain operational amid a lack of support from national institutions points not only to the role of FBOs in addressing humanitarian needs in times of crisis but also to the need for collaboration with other organisations, such as non-governmental and civil society organisations, and individuals in pursuing human and community development.

Table 1 and Table 2 show student registration, classification and the number of teachers at the school in 2008 (the year the AS School started) and in 2016 (when data were collected). These statistics highlight the growing impact and contribution of the school within the community, as more students continued at the school, underlining that the school was an essential intervention in expanding educational opportunities of the youths in the community.

Although the CMC closed down the refugee shelter facilities on 31 December 2014, AS School remained in operation. There was no overwhelming, direct consequence on the operation of the school as a result of the shelter being shut down. Teachers encouraged students to work hard and take inspiration from previous students who had excelled in their studies and had gone on to pursue diverse academic and professional interests (Mkwananzi 2017).

Our research shows that, as a development-oriented intervention strategy, through the $\mathrm{CMC}$, the school, through its social competencies, contributes to human development and capability expansion for marginalised migrant youths in three main ways: (1) meeting basic needs, (2) providing access to education and (3) fostering the capability to aspire for a better life.

\section{Three core human development roles of Albert Street School}

The youths who attended AS School highlighted benefits of attending the school other than access to education. These benefits included meeting basic needs such as providing access to food and clothing and fostering the capability to aspire. As Appadurai (2004) asserts, strengthening the capacity to aspire in individuals with minimum resources, such as marginalised migrants, is vital, as it might help them alter their socio-economic conditions - either in the immediate or long term. 
TABLE 1: Albert Street School registration in 2008

\begin{tabular}{lccc}
\hline Date & School total enrolment & Accompanied learners $^{5}$ & Unaccompanied learners $\dagger$ \\
\hline 14 July 2008 & 35 & 8 & 27 \\
12 September 2008 & 140 & 57 & 93 \\
21 October 2008 & 180 & 84 & 96 \\
07 December 2008 & 220 & 120 & 11 \\
\hline
\end{tabular}

Source: Pausigere, P., 2013, 'Education and training initiatives at the Central Methodist Church Refugee House in Johannesburg', Perspectives in Education 31(2), 42-53

$\dagger$ Child migrants from outside South Africa who migrated on their own.

TABLE 2: Albert Street School registration in 2016 (combined primary and secondary schools).

\begin{tabular}{lcccc}
\hline Date & School total enrolment & Accompanied learners & Unaccompanied learners \\
\hline 13 May 2016 & 323 & 239 & Teaching staff & 84
\end{tabular}

Source: Mkwananzi, F., 2017, 'Exploring the lives and educational aspirations of marginalised migrant youth: A case study in Johannesburg, South Africa', PhD thesis, Centre for Development Support, University of the Free State

\section{Meeting basic needs}

For most of the youths, the initial motivation for attending the school was in order to meet basic needs. The quotations below illustrate:

'When we went to school everything changed, we no longer slept on the stairs of the building; we were bathing, going to school, food was there; we only had to contribute with our brains.' (Paridzai, 25, Male, doing piece jobs)

'When you don't have food, you think of how you are going to get food, in a good way or in a bad way that is where thinking starts. That is when you decide you are going to go this way or that way. I still remember when I didn't have food, which is when I heard about the school, Albert Street School. They were saying that they will give us food, somewhere to sleep and somewhere to bath. So to me, when I first came to Joburg I spent maybe two weeks without bathing, just washing my face.' (Pete, 23, male, Diploma in Electronic Engineering student)

Some of the youths further noted that the decision to attend school was often not prompted by the desire to learn, but by the desire to access food and clothing. Other youths valued the opportunity to be able to take a bath. Thus, the desire to learn came as a result of experiencing the school environment and this influenced their decision to stay in school, just to have access to basic resources for as long as necessary.

The impetus to attend the school because of access to food, clothing and bathing facilities points to the value of meeting elementary human needs, initially for survival, but in the longer term for productive learning. Once the need for threshold-level resources is met, education has the potential to prepare one with means and abilities that broaden opportunities (Wood \& Deprez 2015:13). Thus, education becomes a foundational capability for all individuals to envision, choose and live a life they value. As an educational institution, AS School provided room for the realisation of the capability to be educated, which was possible because the school provided access to resources identified as necessary for a minimally decent life. Educational opportunities alone would not have been sufficient.

The above discussion provides an example of what FBOs can be and do, for example, AS School's social competencies created space for the expansion of other individual 5.Children who migrated with their parents and who might not have been resident at the church shelter, including children of local citizens. capabilities. Through provision of such basic services, AS School promotes wider participation in education by less resourced individuals, in this case migrant youths. The contribution by the school can be viewed as a powerful tool in bringing about positive effects in society, particularly creating awareness of the importance of education (Nishimuko 2009:284). Therefore, despite the unavailability of resources to scale up its services, AS School demonstrates the kind of much needed initiatives in a context with high rates of poverty like South Africa. However, as Day (2010) asserts, such development initiatives continue to be underutilised, yet FBOs continue to be closer to the people than the government, allowing them to identify the most crucial needs that have to be addressed first.

\section{Access to education opportunities}

The O-Level certificate obtained by AS School graduates provided the basis from which they could consider pursuing further education opportunities. The significance of education and of successfully completing the O-Level certificate was highlighted by the youths interviewed who, based on their educational achievements, expressed confidence and feelings of empowerment with regard to realising their aspirations, demonstrating the varied outcomes of their educational opportunities:

'I realised then that there was no future in working for construction companies or doing gardening, so I decided it is better I go to school. I started school, and I started in form one where I had left in Zimbabwe. I completed my O-Levels in 2011 [at AS School], I wrote five subjects and I passed them all. My parents could not take me to school, so this is a precious gift for me.' (Musa, 21, Male, Certificate in Business Management student)

'At Albert, I had a nickname, they used to call me Professor and that is the title which I wanted to be called by in my life; without that I can call myself a failure. When I was doing my O-Level, I told myself that I want to be a professor because of the inspiration I got from professors. We used to go to the seminars and career guidance at the University of Witwatersrand. I also have participated in a young people's parliament and we used to meet professors and the way those professors responded [to our questions] was something that inspired me.' (Elton, 25, male, job seeker)

The migrant youths valued their education received at AS School for different reasons. Amongst the key values of education they mentioned was that it allowed them to earn 
respect, acknowledgement and appreciation from members of society, particularly in their hometowns. In this way, access to and the potential for educational continuation was seen as a tool for both economic and social mobility. Thus, whilst FBOs such as AS School might initially be seen as ways to mitigate particular social crises and meet basic needs, with a simultaneous focus on education, various other capabilities are fostered in the process, such as the capability for respect and social mobility. The expansion of other capabilities strengthens one's aspirations, particularly in contexts where aspirational maps may have been narrow, as asserted by Appadurai (2004). Thus, the literature on both capabilities and development highlights the central role that aspirations play in building better lives (Appadurai 2004; Conradie \& Robeyns 2013; Hart 2016). Clearly, AS School played a critical role in fostering the capability to aspire amongst the marginalised migrant youths who had attended the school.

\section{Fostering the capability to aspire through access to education}

Migrant youths in the study expressed that whilst they all had aspirations in Zimbabwe, they had not thought it was possible to achieve these aspirations because of their social and economic circumstances. Their circumstances constrained the development and promotion of the capability to aspire. According to Hart (2013), promoting the capability to aspire in a supportive setting is a vital starting point for young people, especially to help them avoid the poverty trap. However, in cases of migrant youths, most of whom are within the economically active age range, their individual aspirations are often hindered by the responsibilities and anticipations of those left back home. Usually, those left home anticipate provision from those outside the country, often overlooking age and economic status. This reality could constrain their ability or aspirations of pursuing higher education, even though supportive conditions might be in place. Yet the ability to access and successfully complete education is fundamental for equipping young people for the multiple possible futures they face. Thus, fostering the capability to aspire is key for desired future functioning's for these youths. Table 3 presents the educational aspirations of the young men who had attended AS School before and after migration, as well as their future desired functioning's.

Together with the extracts provided subsequently, Table 3 illustrates how access to education at AS School provided an opportunity for the young men to aspire for other desired beings and doings beyond education. The extracts highlight the contribution of AS School in availing the fundamental elementary capabilities essential for promoting the capability to aspire. The young men's experiences illuminate what migrant men valued by being at the school, such as being exposed to technology and information and identifying one's potential:

'In terms of technology, South Africa is more advanced compared to Zimbabwe. At school you can start using computers, tablets and everything here, but in Zimbabwe it's very rare. Some students are capable of doing that in some schools but they are expensive, but here we are talking of general schools, you can have access to all these things. (Paridzai, 25, Male, doing piece jobs)

'I [now] have little experience, but I couldn't have that experience if I was at home, like opportunities of being called by law firms, just come in and we have these seminars just to learn as students and I think they are beneficial, I don't deny that they might be there at home but I didn't have the opportunity to study at this level at home.' (Terry, 23, Male, Bachelor of Law student)

'I didn't know that I was actually capable of producing more, you know in Zimbabwe they didn't notice our talents, so when I came here and started studying [at AS school], they just noticed my talent like right there and then they started pushing me.' (Henry, 22, Male, Diploma in Business Informatics student)

In addition to the above, most of the youths held the Cambridge certification in high regard and noted that the certificate would be useful back in Zimbabwe, whilst emphasising the exposure gained at the school. Thus, whilst attending AS school might have been driven initially by the need for basic capabilities, the exposure the migrant youths obtained through and at the school altered their view on the potential role of education in their lives, and in the process made aspiring possible. For example, Paridzai highlighted that he was surprised to see that schooling in South Africa was so advanced compared with Zimbabwe. Although he had thought of joining the army or becoming a teacher whilst in Zimbabwe, he now stated that the exposure gained at AS School made him realise that he was interested in studying information technology. Similarly, Lindani noted that, whilst in Zimbabwe, he had lost hope to survive; however, when he attended AS School, he started to see that he could survive and achieve more than he thought possible. Furthermore, the opportunity to attend AS School enhanced the migrant youths' knowledge and critical thinking, which in turn expanded their career choices. For example, Terry changed his aspirations from wanting to become a scientist to becoming a lawyer through exposure and networking with advocates whilst he was at the school. Musa, who received a scholarship to study online after completing his schooling at AS School, believed he had an opportunity to pursue what he wanted to:

'After completing the higher certificate I will get an internship after that if I want to get further with the degree they will see whether I qualify or not so that I can pursue my degree. If I don't qualify with the money I will get, I will either go to UNISA or then do something.' (Musa, 21, Male, Certificate in Business Management Student)

Although the migrant youths may still face some challenges as they navigate their way in the country, as seen in Musa's extract, institutions such as AS School, through their social competence, combined with individual agency, provide an opportunity for young marginalised migrants to strive towards their desired well-being. For most of the men, AS School provided an environment where it was possible to aspire towards what had seemed unachievable whilst living in Zimbabwe.

Though the opportunity to enrol at AS School was open to all migrant children who lived at CMC, mostly men enrolled. 
TABLE 3: Summary of migrants' pre-and post-migration educational aspirations.

\begin{tabular}{|c|c|c|c|c|c|c|}
\hline Pseudonym & $\begin{array}{l}\text { Level of schooling } \\
\text { completed at Albert } \\
\text { Street School }\end{array}$ & $\begin{array}{l}\text { Post-secondary } \\
\text { education at time } \\
\text { of interview }\end{array}$ & $\begin{array}{l}\text { Pre-migration } \\
\text { educational aspirations }\end{array}$ & $\begin{array}{l}\text { Functioning's at time of } \\
\text { interview }\end{array}$ & $\begin{array}{l}\text { Post-migration } \\
\text { educational aspirations }\end{array}$ & Future aspirations \\
\hline Chido & O-Level & Studying & $\begin{array}{l}\text { Accountant or pilot, but his } \\
\text { dreams were disrupted by } \\
\text { poverty and could not think } \\
\text { of anything else. }\end{array}$ & $\begin{array}{l}\text { Studying accounting } \\
\text { (diploma) }\end{array}$ & Complete the diploma & $\begin{array}{l}\text { - Have an educational qualification } \\
\text { financial security be able to take } \\
\text { care of family. }\end{array}$ \\
\hline Elias & O-Level & None & $\begin{array}{l}\text { Information technician, but } \\
\text { father wanted him to study } \\
\text { teaching. }\end{array}$ & Job seeker & $\begin{array}{l}\text { Study information } \\
\text { technology }\end{array}$ & $\begin{array}{l}\text { - Start IT company have dignity and } \\
\text { spiritual freedom peace with } \\
\text { family members happiness. }\end{array}$ \\
\hline Terry & O-Level & Studying & To study science & Studying law (degree) & Complete the degree & $\begin{array}{l}\text { - Run a business help others } \\
\text { financial freedom. }\end{array}$ \\
\hline Henry & O-Level & Studying & $\begin{array}{l}\text { Accountant, but was not } \\
\text { aware he was capable } \\
\text { because of lack of motivation } \\
\text { and support. }\end{array}$ & $\begin{array}{l}\text { Studying business } \\
\text { informatics }\end{array}$ & Complete the diploma & $\begin{array}{l}\text { - Start IT company be successful } \\
\text { give back to community empower } \\
\text { young people financial security be } \\
\text { happy. }\end{array}$ \\
\hline Pete & O-Level & Studying & $\begin{array}{l}\text { Pilot, but thought of joining } \\
\text { the army because of the } \\
\text { challenges. }\end{array}$ & $\begin{array}{l}\text { Studying engineering } \\
\text { (diploma) }\end{array}$ & Study mechatronics & $\begin{array}{l}\text { - Have a home and a family } \\
\text { financial security open an } \\
\text { orphanage successful career } \\
\text { provide for family. }\end{array}$ \\
\hline Sipho & O-Level & None & Pilot or a policeman & Job seeker & $\begin{array}{l}\text { Study information } \\
\text { technology }\end{array}$ & $\begin{array}{l}\text { - Get a degree in IT build a house } \\
\text { for his grandmother care for } \\
\text { family open a children's home. }\end{array}$ \\
\hline Rusu & O-Level & None & Accountant & Job seeker & Study film & $\begin{array}{l}\text { - Be educated have shelter be able } \\
\text { to provide for family live a better } \\
\text { life }\end{array}$ \\
\hline Elton & O-Level & $\begin{array}{l}\text { Dropped out of } \\
\text { university because } \\
\text { of financial } \\
\text { challenges }\end{array}$ & To study medicine & Job seeker & $\begin{array}{l}\text { Complete the degree in } \\
\text { environmental } \\
\text { management and become } \\
\text { a professor }\end{array}$ & $\begin{array}{l}\text { - Have a family financial } \\
\text { independence recognition (for } \\
\text { achievements). }\end{array}$ \\
\hline Musa & O-Level & Studying & $\begin{array}{l}\text { No educational aspirations } \\
\text { and never dreamt of } \\
\text { becoming somebody, } \\
\text { thought he would become a } \\
\text { truck driver or a mechanic. }\end{array}$ & $\begin{array}{l}\text { Studying business } \\
\text { management (certificate) }\end{array}$ & Complete the certificate & $\begin{array}{l}\text { - Get a degree and be a } \\
\text { professional secure employment } \\
\text { financial security providing for } \\
\text { family. }\end{array}$ \\
\hline Paridzai & O-Level & None & $\begin{array}{l}\text { Politician or army officer or } \\
\text { teacher }\end{array}$ & Doing piece jobs & Study IT & $\begin{array}{l}\text { - Run his own IT company be } \\
\text { respected (for his achievements) } \\
\text { financial independence give back } \\
\text { to community. }\end{array}$ \\
\hline Lindani & O-Level & None & $\begin{array}{l}\text { Hoped only to survive. Never } \\
\text { believed in the power of } \\
\text { education. }\end{array}$ & Job seeker & Study BA Journalism & $\begin{array}{l}\text { Be educated travel the world } \\
\text { financial independence job } \\
\text { security give back to community } \\
\text { start a family. }\end{array}$ \\
\hline Lesley & O-Level & None & $\begin{array}{l}\text { Police officer, but his father } \\
\text { wanted him to attend Bible } \\
\text { School. }\end{array}$ & Job seeker & Study IT and film & $\begin{array}{l}\text { - Be a role model have secure } \\
\text { employment recognition (for his } \\
\text { achievements). }\end{array}$ \\
\hline
\end{tabular}

Source: Adapted from Mkwananzi, F., 2017, 'Exploring the lives and educational aspirations of marginalised migrant youth: A case study in Johannesburg, South Africa', PhD thesis, Centre for Development Support, University of the Free State

None of the young women who participated in the study had attended AS School. As highlighted earlier, this might be because most of the young women, upon arrival in South Africa, found live-in domestic work. This could also be ascribed to other societal and gendered expectations and the responsibilities attached to such expectations. One of the reasons given by the young women on why they had not attended free-access education at AS School was related to age, as shown below:

'I thought I was too old to go back to school. I asked myself what I will be doing in school at 21 when there are probably young children of 15 years of age.' (Neo, 27, Female, job seeker)

When asked about their short-term aspirations, most young women noted that they wanted financial stability so that they could provide for their families back home. This was contrary to men, particularly those who had completed the O-Level at AS School, whose short-term aspirations were related to 'enrolling for a diploma and/or degree' or 'completing my diploma and/or degree'. Although the migrant men interviewed acknowledged the significance of financial returns, most of them believed that the desired income would be obtainable once they become educated. The view held by the migrant men was that education would expand their opportunities for employment and they would then afford the lifestyle they desired (e.g. ability to buy a house and a car). Thus, an institution such as AS School, through access to education, allowed the capability of aspiring for a better life to seem possible for the migrant men. Through education, there is hope for leading desired and valued lives. This shows how AS School, through its social competencies, was key in shaping the aspirations of the migrant men as they navigated their way in a foreign land.

We noted earlier that most young migrant women often took up domestic work upon arrival, and in this specific case did not utilise the social competencies of AS School. This could be attributed to the traditionally gendered roles ascribed to men and women, particularly on what one ought to do or to have achieved either at a certain age or because of one's gender. This is seen in Nancy's view when she asserted '... when I look at my age, I am now a mum, and everyone is looking up to me, sometimes I think it is unnecessary [to go to school]'. However, the need remains to gain a deeper understanding of these notions, which have an impact on both agency and aspirations. As such, further specific research is required into gender, agency and aspirations formulation and what this might mean 
for human development. In the next section, we illustrate how social competencies created by AS School and individual agency functioned together in the formation of migrant youths' educational aspirations.

\section{Ethical clearance}

This study was approved by the University of the Free State (UFS-EDU-2014-043).

\section{Intersections of social competencies of Albert Street School and young people's agency}

DenJaeghere (2016) highlights the importance of agency even in the presence of social competencies. This was confirmed by our data, which illustrated the instrumentality of the social competencies created by AS School and how this is key in developing the capability to aspire amongst young migrant men. Thus, the relationship between aspirations and agency should be seen as dialectical within a given social context. This dialectical connection changes over time and DeJaeghere proposes that the effect of aspirations and agency be considered when looking at one's valued well-being. Thus, the effectiveness of these available competencies, through AS School could also be attributed to the individual agency exercised by some of the migrant youths. In the presence of favourable conditions, the effect of agency is helpful in understanding the extent of freedom available in bringing about the achievements desired by the migrant youths.

For most of the migrant men in the study, agency was seen in their decisions to take up the opportunity to study at AS School when they could have continued to search for jobs for survival in South Africa. Given DeJaeghere's (2016) assertion of the intersectionality of aspirations, agency and social conditions, we relate aspiration formation to a fourfold aspirations conceptualisation (see Mkwananzi 2017). These are resigned, agentic, persistent and frustrated aspirations. We specifically focus on social competencies and agency as illustrated in Figure 1.

\section{Resigned aspirations}

Resigned aspirations are placed at the intersection of available social competencies and low levels of agency operating within the aspirations window, ${ }^{6}$ shown in Neo's quote above. Whilst an institution such as AS School may be in place as a positive condition for pursuing educational aspirations, issues such as age influenced Neo's choice to not take up this opportunity. This suggests that aspirations become resigned to the fact that studying is not possible because of other circumstances in one's life. Thus, the interaction of conversion factors resulting in the resignation of aspirations is multifaceted, and it can involve various dimensions of one's life (such as personal, economic, social and cultural influences).

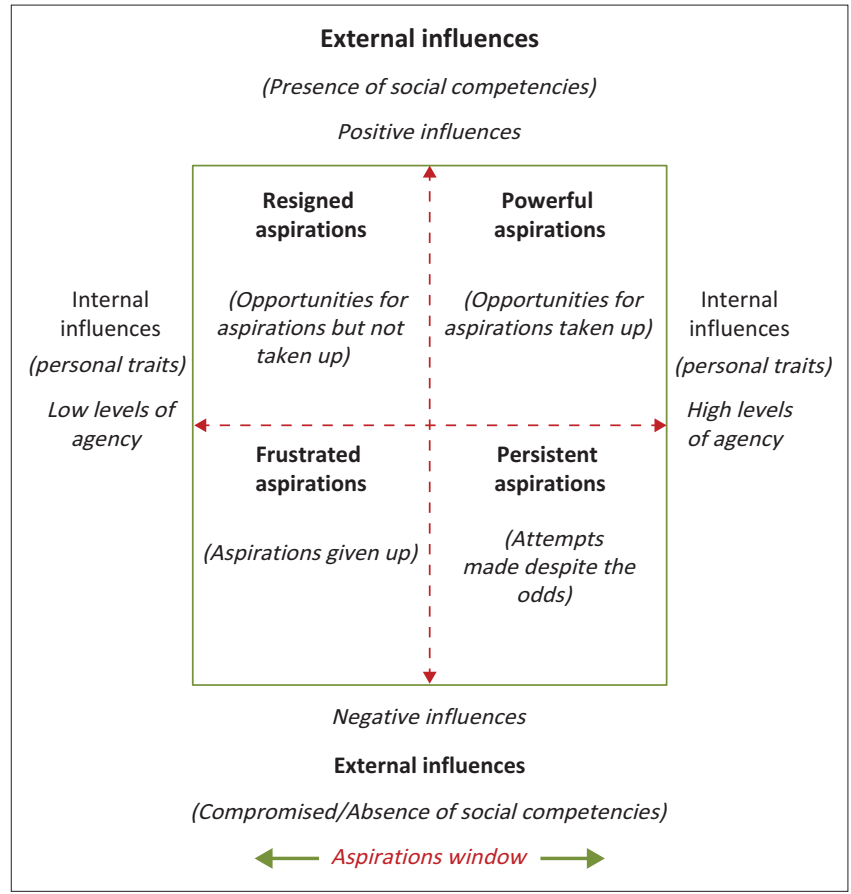

Source: Adapted from Mkwananzi, F., 2017, 'Exploring the lives and educational aspirations of marginalised migrant youth: A case study in Johannesburg, South Africa', PhD thesis, Centre for Development Support, University of the Free State

FIGURE 1: Relationship between social competencies and agency in aspirations formation.

\section{Powerful aspirations}

Musa's extract highlights powerful aspirations, where the intersection of available social competencies converges with high levels of agency operating within the aspirations window. The individual has control over various dimensions of life such as the emotional, physical and mental states of being. These states of being exist in flexible social and structural settings, which may include higher education, migration and/or labour policies, and access to schooling. Such clear aspirations indicate a positive interaction between an individual's high levels of agency and a positive environment. However, the allusion to social competencies does not propose that the existing positive environment would automatically make it easy for individuals to raise or form their educational aspirations. Instead, it puts forward that, despite one's circumstances, one might decide to see potential and possibilities in an otherwise challenging context. Hence, understanding the nuanced intersection of agency and social conditions is essential.

\section{Persistent aspirations}

As seen in Table 3, Elton provides an example of persistent aspirations, which lie at the intersection of compromised social competencies and high levels of agency operating within an aspirations window. In Elton's case, whilst social competencies had been available through AS School, other structural factors (such as finance) made it difficult for him to realise these aspirations, therefore compromising the effects of a positive condition. This could mean that his desire of 
becoming a professor could take longer to realise because of the prevailing conditions at a given time and not because the desire itself is unattainable. If Elton's agency could be coupled with opportunity, his aspirations would have the potential to shift from persistent to powerful. Clearly, it is essential for an individual to continuously and actively search for potential opportunities instead of believing that opportunities will avail themselves in the future.

\section{Frustrated aspirations}

Most of the young migrants, particularly men who had neither completed their secondary schooling in Zimbabwe nor attended AS School, highlighted frustrated aspirations. This type of aspiration formation lies at the intersection of absent social competencies and low levels of agency operating within the aspirations window. The interaction of these two contexts can lead to a condition where an individual lacks self-confidence in the social and structural conditions present. Similar to resigned aspirations, various factors may lead to low levels of agency, such as a lack of motivation or individual background. Low agency is continually accompanied by a lack of conducive conditions such that the aspiring individual develops a perception that there is a lack of opportunities.

With the different formulations of educational aspirations mentioned earlier, the conception of 'imagining alternative futures' forwarded by DeJaeghere (2016:3) becomes valuable in considering the decisions and choices of the migrant youths in redirecting their aspirations within these narratives. Because of different personal factors, individuals will experience changing aspirations as lives continue to be fluid at different points. Thus, aspirations often do not remain fixed, even in the presence of social competencies such as those provided by AS School or other FBOs. Hence, assessment of any conditions and opportunities should consider agency, particularly agency exercised in difficult conditions.

\section{Conclusion}

In this article, we have shown how FBOs can be 'significant purveyors of education, service delivery and other nonmarket goods' (Alkire 2006:3) through creating social competencies that have a long-term impact on individual lives, in this case access to education, thereby advancing other capabilities in the lives of individuals. One of these capabilities is the ability to aspire towards a better life. This has been highlighted throughout the article by illustrating the significant influence of one FBO on the aspirations of marginalised migrant youths. Whilst the interaction of social competencies created by the FBO, individual agency and aspirations has shown the complexity in the formation of educational aspirations amongst marginalised migrant youths; based on our normative analysis, we conclude that despite the complexity, the findings presented in this article provide a rich example of how FBOs can meaningfully contribute to human development and capability expansion for marginalised groups.

\section{Acknowledgements}

\section{Competing interests}

The authors declare that they have no competing interests with regard to the writing of this article.

\section{Authors' contributions}

Both authors made a substantial scholarly contribution to the writing of this article based on conceptualisation, analysis and interpretation of research data and critically revised all sections that needed revision.

\section{References}

Act Alliance, 2018, Symposium on the role of religion and FBOs. Perspectives on migration: Displacement and marginalization, inclusion and justice, viewed 15 July 2018, from http://actalliance.org/act-news/2018-symposium-on-the-role-ofreligion-and-fbos-perspectives-on-migration-displacement-and-marginalizationinclusion-and-justice/

Alkire, S., 2006, 'Religion and development', in D.A. Clark (ed.), The Elgar companion to development studies, pp. 502-510, Edward Elgar, Cheltenham.

Appadurai, A., 2004, 'The capacity to aspire: Culture and the terms of recognition', in V. Rao \& M. Walton (eds.), Culture and public action, pp. 59-84, Stanford University Press, Stanford, CA.

Besada, H., 2011, Zimbabwe: Picking up the pieces, Palgrave MacMillan, New York.

Calitz, T.M.L., Wilson-Strydom, M. \& Walker, M., 2016, 'Theorising a capability approach to equal participation for undergraduate students at a South African university', Perspectives in Education 34(2), 57-69. https://doi.org/10.18820/251 9593X/pie. v34i2.5

Carino, T.C., 2016, 'Faith-based organisations between service delivery and social change in contemporary China: The experience of Amity Foundation', HTS Teologiese Studies/ Theological Studies 72(4), a3504. https://doi.org/10.4102/hts.v72i4.3504

Chaves, M., 2001, Religious congregations and welfare reform, viewed 17 February 2018, from https://link.springer.com/content/pdf/10.1007/s12115-001-1036-3.pdf

Chirisa, I. \& Muchini, T., 2011, 'Youth, unemployment and peri-urbanity in Zimbabwe: A snapshot of lessons from Hatcliffe', International Journal of Politics and Good Governance 2(2.2), 1-15.

Clarke, G. \& Jennings, M. (eds.), 2008, Development, civil society and faith-based organisations: Bridging the sacred and the secular, Palgrave MacMillan, Hampshire.

Conradie, I. \& Robeyns, I., 2013, 'Aspirations and human development interventions', Journal of Human Development and Capabilities 14(4), 559-580. https://doi.org/ Journal of Human Development and
10.1080/19452829.2013.827637

Day, J.V., 2010, 'The role of faith-based organisations in poverty alleviation in South Africa: Challenging Putnam's conception', Master's thesis, Faculty of Humanities, Development and Social Science, University of KwaZulu Natal.

DeJaeghere, J., 2016, 'Girls' educational aspirations and agency: Imagining alternative futures through schooling in a low-resourced Tanzanian community', Critical Studies in Education 59 (2), 237-255. https://doi.org/10.1080/17508487.2016.1188835

Dekker, M., 2009, Livelihoods and economic crisis: The case of smallholder farmers in Zimbabwe (1999-2008), Centre for the Study of African Economies, University of Oxford, Oxford.

Deneulin, S., 2009, 'Part II: Religion', in S. Deneulin \& L. Shahani (eds.), An introduction to the human development and capability approach: Freedom and agency, pp. 261-271, Earthscan, London.

Deneulin, S. \& Bano, M., 2009, Religion in development: Rewriting the secular script, Palgrave MacMillan, London.

Deneulin, S. \& Zampini-Davies, A., 2016, 'Theology and development as capability', HTS Teologiese Studies/Theological Studies 72(4), 1-9. https://doi.org/10.4102/ hts.v72i4.3230

Deneulin, S. \& Zampini-Davies, A., 2017, 'Engaging development and religion: Methodological groundings', World Development 99 (Nov), 110-121. https://doi. org/10.1016/j.worlddev.2017.07.014

Fiddian-Qasmiyeh, E., 2011, 'Introduction: Faith-based humanitarianism in contexts of forced displacement', Journal of Refugee Studies 24, 429-439. https://doi. org/10.1093/jrs/fer033

Hanke, S., 2017, Zimbabwe: From disaster to disaster, viewed 05 July 2018, from https://www.forbes.com/sites/stevehanke/2017/07/31/zimbabwe-fromdisaster-to-disaster/\#132f51c1221a

Hanke, S.H. \& Kwok, A.K.F., 2009, 'On the management of Zimbabwe's hyperinflation', Cato Journal 29(2), 353-363.

Hart, C.S., 2013, Aspirations, education and social justice: Applying Sen and Bourdieu, Bloomsbury, London \& New York.

Hart, C.S., 2016, 'How do aspirations matter'? Journal of Human Development and Capabilities 17, 324-341. https://doi.org/10.1080/19452829.2016.1199540 
Kuljian, C., 2013, Sanctuary: How an inner-city church spilled onto a sidewalk, Jacana Media, Sunnyside.

Makumbe, J., 2009, The impact of democracy in Zimbabwe: Assessing political, social and economic developments since the dawn of democracy, viewed 23 March 2018, from http://cps.org.za/cps\%20pdf/RR119.pdf

Mkwananzi, F., 2017, 'Exploring the lives and educational aspirations of marginalised migrant youth: A case study in Johannesburg, South Africa', PhD thesis, Centre for Development Support, University of the Free State.

Mkwananzi, F. \& Wilson-Strydom, M., 2018, 'Multidimensional disadvantages and educational aspirations of marginalised migrant youth: Insights from the Global South', Journal of Global Ethics 14(1), 71-94. https://doi.org/10.1080/17449626. 2018.1496349

Nishimuko, M., 2009, 'The role of non-governmental organisations and faith-based organisations in achieving Education for All: The case of Sierra Leone', Compare 39(2), 281-295. https://doi.org/10.1080/03057920902750525

Occhipinti, L.A., 2015, 'Faith-based organizations and development', in E. Tomalin (ed.), The Routledge handbook of religions and global development, pp. 331-345, Routledge, London.

Olarinmoye, O., 2012, 'Faith-based organisations and development: Prospects and constraints', Transformation 29, 1-14. https://doi.org/10.1177/0265378811427985

Pausigere, P., 2013, 'Education and training initiatives at the Central Methodist Church Refugee House in Johannesburg', Perspectives in Education 31(2), 42-53.

Pswarayi, L. \& Reeler, T., 2012, Fragility and education in Zimbabwe: Assessing the impact of violence on education, viewed 04 May 2016, from http://www. protectingeducation.org/sites/default/files/documents/fragile_state_and education in zimbabwe december_2012.pdf

Ray, D., 2006, 'Aspirations, poverty, and economic change', in A.V. Banerjee, R. Benabo \& D. Mookherjee (eds.), Understanding poverty, pp. 409-421, Oxford University Press, Oxford.

Robeyns, I., 2011, The capability approach, viewed 08 July 2018, from http://plato. stanford.edu/entries/capability-approach/
Robeyns, I., 2017, Wellbeing, freedom and social justice: The capability approach reexamined, Open Book Publishers, Cambridge.

RSA Government, 1996, National Youth Commission Act, No. 19 of 1996, Government Printers, Pretoria.

RSA Government, 1998, Refugees Act, No. 130 of 1998, Government Printers, Pretoria.

RSA Government, 2002, Immigration Act, No. 13 of 2002, Government Printers, Pretoria.

Sen, A., 1999, Development as freedom, Oxford University Press, Oxford.

Stewart, F., 2013, Capabilities and human development: Beyond the individual The critical role of social institutions and social competencies, Human Development Report Occasional Papers 2013/03, Human Development Report Office, New York.

Swart, I. \& Nell, E., 2016, 'Religion and development: The rise of a bibliography', HTS Teologiese Studies/Theological Studies 72(4), a3862. https://.doi.org/10.4102/ hts.v72i 4.3862

Trimikliniotis, N., Gordon, S. \& Zondo, B., 2009, 'Globalisation and migrant labour in a "Rainbow Nation": A fortress South Africa?', in R. Munck (ed.), Globalization and migration: New issues, new politics, pp. 95-111, Routledge Taylor and Francis Group, London and New York.

UNICEF, 2009, Zimbabwe education crisis worsens, viewed 13 March 2018, from http://www.unicef.org/media/media_47915.html

Willis, O., 2013, 'Religion and international development in the Canadian academic context', Canadian Journal of Development Studies 34, 275-290. https://doi.org/ 10.1080/02255189.2013.782269

World Bank, 2004, World Development Report 2004. Making services work for poor people, World Bank, Washington, DC.

Wood, D. \& Deprez, L.S., 2015, 'Re-imagining possibilities for democratic education: Generative pedagogies in service to the capability approach', Learning for Democracy 5(3), 5-31. 